\title{
Efficient production of human acidic fibroblast growth factor in pea (Pisum sativum L.) plants by agroinfection of germinated seeds
}

Yajun Fan ${ }^{1,2}$, Wei Li ${ }^{1}$, Junjie Wang ${ }^{3,1}$, Jingying Liu', Meiying Yang ${ }^{4}$, Duo Xu ${ }^{1}$, Xiaojuan Zhu ${ }^{1}$ and Xingzhi Wang ${ }^{1 *}$

\begin{abstract}
Background: For efficient and large scale production of recombinant proteins in plants transient expression by agroinfection has a number of advantages over stable transformation. Simple manipulation, rapid analysis and high expression efficiency are possible. In pea, Pisum sativum, a Virus Induced Gene Silencing System using the pea early browning virus has been converted into an efficient agroinfection system by converting the two RNA genomes of the virus into binary expression vectors for Agrobacterium transformation.

Results: By vacuum infiltration (0.08 Mpa, $1 \mathrm{~min}$ ) of germinating pea seeds with $2-3 \mathrm{~cm}$ roots with Agrobacteria carrying the binary vectors, expression of the gene for Green Fluorescent Protein as marker and the gene for the human acidic fibroblast growth factor (aFGF) was obtained in $80 \%$ of the infiltrated developing seedlings. Maximal production of the recombinant proteins was achieved 12-15 days after infiltration.

Conclusions: Compared to the leaf injection method vacuum infiltration of germinated seeds is highly efficient allowing large scale production of plants transiently expressing recombinant proteins. The production cycle of plants for harvesting the recombinant protein was shortened from 30 days for leaf injection to 15 days by applying vacuum infiltration. The synthesized aFGF was purified by heparin-affinity chromatography and its mitogenic activity on NIH 3 T3 cells confirmed to be similar to a commercial product.
\end{abstract}

\section{Background}

The acidic mammalian fibroblast growth factor (aFGF) and the basic fibroblast growth factor (bFGF) bind to heparin decasaccharide and to domains of their tyrosine membrane spanning kinase receptor $[1,2]$. FGF is a powerful mitogen in many mammalian cell types. However its major importance is to switch endothelial cell growth to angiogenesis (formation of blood vessels) and to development of tumors $[3,4]$.

Depending on the cell growth substrate FGF either stimulates endothelial cell growth or promotes capillary differentiation. Extensive cell spreading and growth were stimulated when the culture dishes were pre-coated with a high density of the extracellular matrix protein fibronectin $\left(>500 \mathrm{ng} / \mathrm{cm}^{2}\right)$ whereas lower coating densities $\left(100-500 \mathrm{ng} / \mathrm{cm}^{2}\right)$ resulted in cell shortening,

\footnotetext{
* Correspondence: mailwxz@yahoo.com.cn

${ }^{1}$ Institute of Genetics and Cytology, Northeast Normal University, Changchun 130024, China

Full list of author information is available at the end of the article
}

cessation of growth and tube formation. Coating with different concentrations of type IV collagen or gelatin resulted in similar switches.

It is now recognized that oncogene induced excessive tumor cell proliferation is insufficient to produce a lethal tumor but requires simultaneous angiogenesis [3]. Tumor cell proliferation alone without angiogenesis frequently gives rise to dormant, microscopic tumors. The latter can be reactivated by increased angiogenic activity unless there is a permanent inhibition of this activity by endogenous angiogenesis inhibitors. Therefore there is interest in the efficient and cost effective production of recombinant FGFs for experiments in these areas.

In general, there are two major strategies for production of recombinant proteins of agricultural, nutritional or medical interest from genes introduced into plants: Stable transformation and transient expression. Transient expression has a number of advantages over stable transformation [5-13]. Simple manipulation, rapid analysis and high expression efficiency are possible. Primarily it avoids the
C Biomed Central

(c) 2011 Fan et al; licensee BioMed Central Ltd. This is an Open Access article distributed under the terms of the Creative Commons Attribution License (http://creativecommons.org/licenses/by/2.0), which permits unrestricted use, distribution, and reproduction in any medium, provided the original work is properly cited. 
extensive isolation, complex safety regulations and bureaucracy connected with growing stable transformed plants in the field. Previously tobacco, lettuce, tomato, cucumber and indica or japonica rice have been employed as transient expression hosts [14-20]. In addition some legume species such as alfalfa have been successfully used for production of monoclonal antibodies and blood substitutes [21]. Intact leaf vacuum system for transient expression of recombinant proteins by Agrobacterium was applied in 1997 to Phaseolus acutifolius, Phaseolus vulgaris, poplar and tobacco [16]. The vacuum was exerted on detached leaves and the plant materials were difficult to preserve fresh after inoculation. However, the transformation of other legume crops have been difficult and there is only one previous report of transient expression of recombinant proteins of medical or industrial interest in peas. Green et al. used this method to express three therapeutic proteins: hGH, HAWY1, and LicKM-PAD4 in Pisum sativum (green pea) varieties, the plants were grown for 7-14 days before vacuum infiltration [22]. We have used pea here and converted the pea early browning virus (PEBV) Virus Induced Gene Silencing System (VIGS) to an efficient agroinfection system [23]. PEBV belongs to the tobacco rattle virus genus, which has provided efficient silencing vectors for tobacco and tomato [24-28]. PEBV is a rod-shaped virus with a bipartite RNA genome [29]. The RNA1 molecule encodes all proteins required for replication and movement of the virus and can infect plants without RNA2. RNA2 encodes the viral coat protein and proteins needed for nematode transmission. PEBV has been modified into binary expression vectors for Agrobacterium transformation by inserting the expression cassettes of RNA1 and RNA2 between the right and left TDNA borders of CAMBIA 1300 derived plasmids. Transcriptional control is exerted by a cauliflower mosaic virus $35 \mathrm{~S}$ promoter and a nopaline syntase (NOS) terminator. Plasmid pCAPE1 contains the full-length cDNA of PEBV RNA1 with an intron inserted to stabilize the plasmid in bacteria. Plasmid pCAPE2-GFP contains the cDNA of PEBV RNA2 with the green fluorescent protein (GFP) coding sequence under the control of the coat protein promoter replacing the genes required for nematode transmission. Alternatively the genes for nematode transmission are replaced with the gene whose expression is desired, in casu the gene encoding human fibroblast growth factor. The two Agrobacterium strains with these two plasmids are mixed and the mixture delivered into the leaves with a syringe. (i) The plant RNA polymerase transcribes the full length cDNA of PEBV RNA1 including the encoded viral RNA polymerase from the T-DNA chromosomal insertions (ii) Transcription and translation of the RNA1 related genes permit the assembly of the viral components that spread the virus throughout the plant. (iii) The plant RNA polymerase transcribes simultaneously the
pCAPE2 T-DNA chromosomal insertion encoding the virus coat protein and the targeted transgene. Translation provides the two proteins in the cells, i.e the desired recombinant protein and virus particles both spread throughout the plant.

Several different methods have been used to inoculate Agrobacterium into plants. Leaf injection is an effective way to introduce Agrobacterium containing genes of interest into plant leaves. We have previously used this method to express the human acidic fibroblast growth factor (aFGF) in tobacco leaves [15]. But leaf injection is laborious, and requires repeated injection of each plant leaf. Therefore leaf vacuum infiltration has been used for expression of $\beta$-glucuronidase in Phaseolus vulgaris [16] and for synthesis of tumor-specific single-chain and chimerical antibodies in tobacco leaves [30]. Vacuum infiltration has also been used to express an active human beta-interferon in lettuce and to transform lentil cotyledonary nodes and wheat inflorescence tissues [14,31,32].

We present here a useful transient plant expression system for recombinant proteins in pea plants by vacuum infiltration of germinating seeds with two Agrobacterium strains carrying the pCAPE1 and pCAPE2-GFP or pCAPE2-aFGF plasmid, respectively. Using GFP as reporter conditions were optimized and the procedure applied to synthesise human acidic fibroblast growth factor (aFGF) in pea plants. Western blot analyses confirmed the production of aFGF and a bioassay of mitogenic activity demonstrated that the purified recombinant aFGF was active in stimulating the growth of NIH 3T3 cells.

\section{Results}

Vacuum infiltration system for germinated pea seeds

Pea seeds with 2-3 cm roots (Figure 1c) were exposed to a solution of Agrobacterium containing GFP encoding T-DNA at a density of $\mathrm{OD}_{600}=1.0-1.5$ and to a vacuum of $0.08 \mathrm{MPa}$ for $1,5,10$ or $15 \mathrm{~min}$. At 8-10 dpi GFP fluorescence was observed. The spreading of fluorescence into newly formed leaves continued for 15 days when the plants were harvested and GFP expression was analyzed. The result indicated that the frequency of GFP expressing plants was independent of the times of vacuum treatment (Figure $2 \mathrm{a}$ ). One min vacuum treatment was adopted for the following tests.

Vacuum pressure treatments were performed at 0.02 , $0.04,0.06$ and $0.08 \mathrm{MPa}$ using a cell density $\mathrm{OD}_{600}=1.0$ 1.5 , and a evacuation time of one min. The frequency of GFP expressing plants was $0,5 \%, 38 \%$ and $82 \%$ at pressures of $0.02,0.04,0.06$ and $0.08 \mathrm{MPa}$ (Figure $2 \mathrm{~b}$ ) respectively, indicating that the vacuum pressure was a key factor for successful agroinfection. The highest number of transient expressing GFP plants were observed with the highest vacuum pressure tested (0.08 $\mathrm{MPa})$. No GFP-positive plants were obtained at $0.02 \mathrm{MPa}$. 


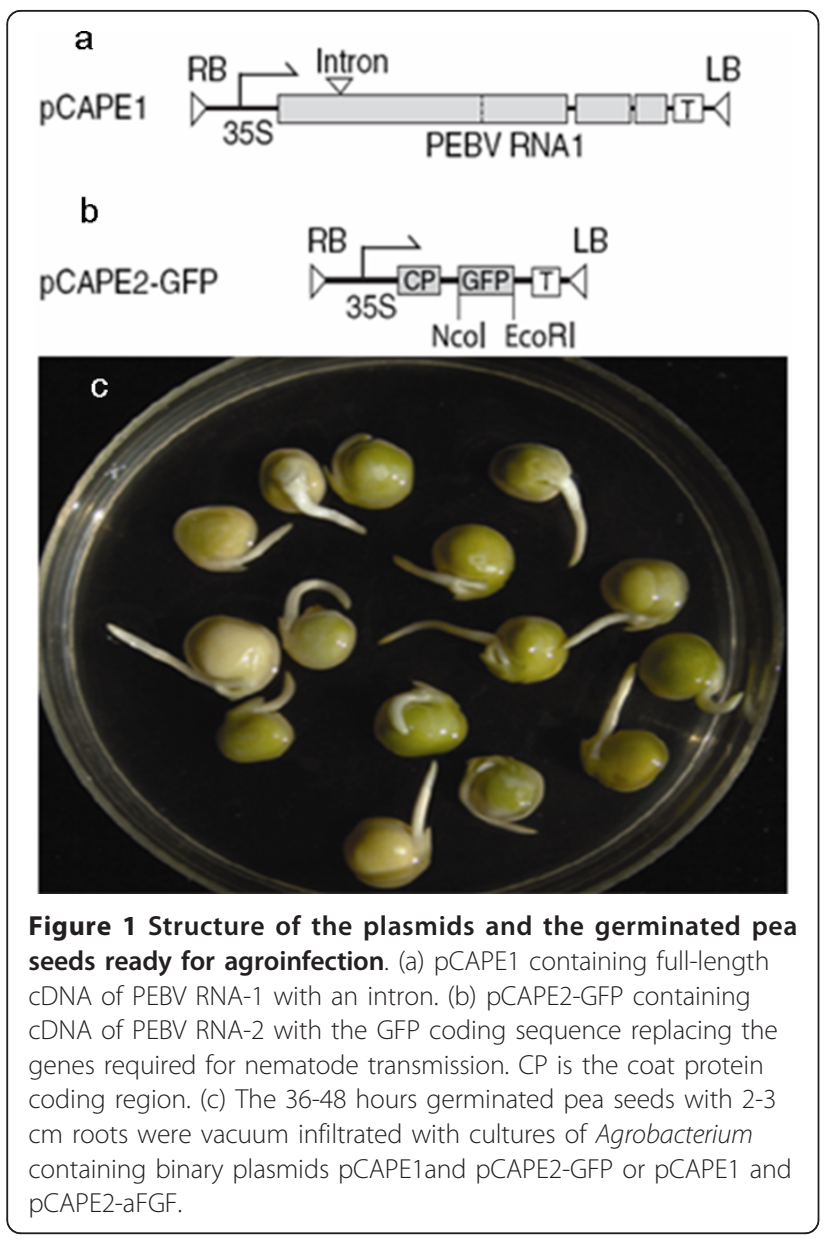

To determine if wounding affected the inoculation, germinated seeds with root wounding or with intact roots were immersed in Agrobacterium suspensions (bacterium density $\mathrm{OD}_{600}=1.0-1.5$ ) and vacuum applied for $1 \mathrm{~min}$ at $0.08 \mathrm{MPa}$ vacuum pressure. The frequency of GFP expressing was $74.6 \%$ and $75.7 \%$ in plants inoculated with and without root wounding indicating that wounding did not affect the induction of GFP expression (Figure 2c).

Our data indicated that bacterium suspension density was another important factor influencing the frequency of induction of GFP expression. Bacterium suspension densities of $0.3,0.6,0.9,1.2$ and $1.5\left(\mathrm{OD}_{600}\right)$ were used for inoculation at $0.08 \mathrm{MPa}$ vacuum pressure for $1 \mathrm{~min}$. The percentage of GFP expressing plants was above $79 \%$ with a suspension density exceeding $0.9 \mathrm{OD}_{600}$ (Figure $2 \mathrm{~d}$ ).

\section{Comparison of GFP expressing plants obtained with vacuum infiltration of germinated seeds with Agrobacterium versus leaf injected plants}

Germinated pea seeds were vacuum infiltrated $(0.08$ $\mathrm{MPa}, 1 \mathrm{~min}, \mathrm{OD}_{600}=1.2$ ) or injected into the backside of the young leaves on 2-week-old pea plants using a
1 - $\mathrm{ml}$ syringe $\left(\mathrm{OD}_{600}=1.2\right)$. GFP fluorescence was monitored at 8-10 dpi. In the vacuum infiltrated seedlings GFP was first expressed in the stem and reached its highest value in both leaves and stems at 12-15 dpi (Figure 3a-3c). With leaf injection, GFP fluorescence was first visualized in treated leaves at 8-10 dpi (the same as with vacuum infiltration of germinated seeds), and GFP was detected in stems and upper non-agroinfected leaves on the next day. In the following two days the diffused GFP was more extensive in leaves (Figure 3d-3f). The amount of GFP tended to decrease with both of the treatments at 15-16 dpi. At 18-20 dpi the GFP fluorescence had almost disappeared. However, there was another peak of GFP expression in the upper stems in vacuum infiltrated plant leaves 6-7 days later.

\section{GFP and aFGF protein analysis}

Western blot analysis was used to compare the two methods. The total soluble proteins in 20 plants agroinfected with GV3101-pCAE2-GFP and GV3101-pCAE1 were extracted. The results showed single bands for GFP or aFGF by Western blot (Figure $4 \mathrm{a}-4 \mathrm{~d}$ ). The amount of GFP or aFGF expressed in vacuum-infiltrated plants was similar to that obtained by leaf injection: GFP was $1 \%$ of the plant total soluble protein.

\section{Mitogenic activity of pea plant-derived aFGF protein}

The activity of the pea plant-derived acid fibroblast growth factor (aFGF) was determined by a bioassay determining the mitogenic activity elicited in NIH 3T3 cells. Concentrations of aFGF in the NIH 3T3 cell cultures ranged from 125 to $625 \mathrm{ng} / \mathrm{ml}$. The growth of $3 \mathrm{~T} 3$ cells were stimulated significantly both by pea plantderived aFGF and the commercial aFGF (Figure 5). The highest stimulation was obtained at $50 \mathrm{ng}$ aFGF added to $100 \mu \mathrm{l}$ cell culture.

\section{Discussion}

Importance of endothelic growth factors

With the discovery that oncogene induced excessive tumor cell proliferation is angiogenesis dependent the angiogenesis inducing activity of acid and basic FGFs as well as that of the vascular endothelic growth factor (VEGF) has become of great interest. Efficient and costeffective production of these growth factors and other proteins involved in neovascularization are of prime importance in the analysis of the function of natural and synthetic inhibitors of the network of capillary tubes stimulated by these growth factors [3]. Tumor cell proliferation in the absence of angiogenesis can give rise to dormant microscopic tumors of $1 \mathrm{~mm}^{3}$ or less but these in situ cancers are harmless to the host. However a switch to the angiogenic phenotype permits these 


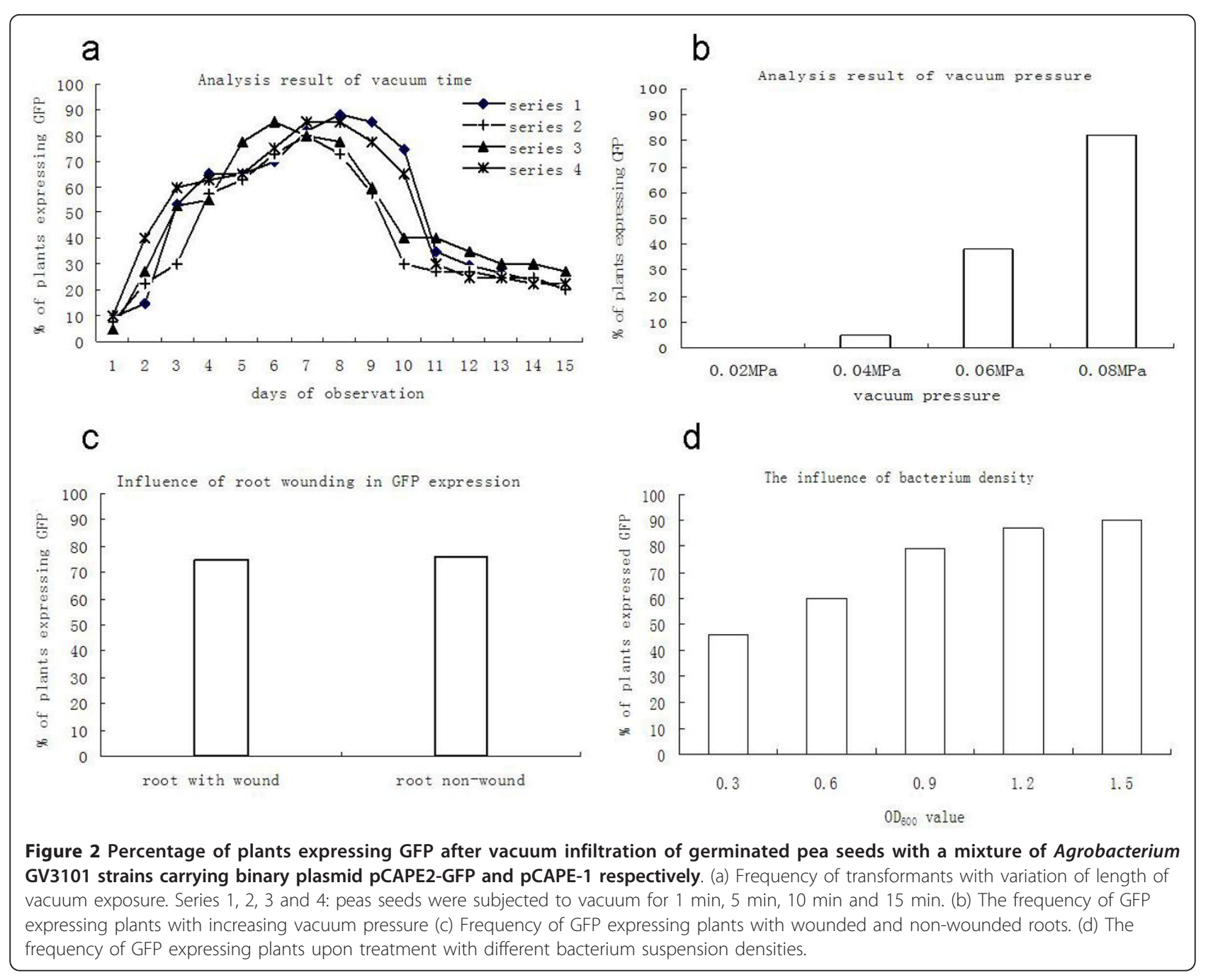

dormant cancers to become rapidly growing tumors that can subsequently metastasize $[4,33,34]$.

The gene participants in the angiogenic switch have recently been determined [33]. Human dermal endothelial cells isolated from two different human donors were treated for $4 \mathrm{~h}$ with (i) Vascular endothelial growth factor (VEGF) $\left(10 \mathrm{ng} \cdot \mathrm{ml}^{-1}\right)$, (ii) bFGF (20ng. $\mathrm{ml}^{-1}$ ) (iii) combined VEGF plus bFGF and (iv) endostatin $\left(200 \mathrm{ng} \cdot \mathrm{ml}^{-1}\right)$. After isolation of total RNA from these cells upregulated and downregulated transcripts by the treatments were determined by microarray analysis of 74,834 human cDNA clones. Expression levels of the RNA transcripts were quantitated by real time PCR. After treatment with endostatin 1,230 genes were significantly upregulated. These same genes were simultaneously down regulated after treatment with bFGF, and VEGF+BFGF and are thus considered participants in anti-angiogenic signaling. Conversely 1,140 transcripts downregulated by endostatin were found upregulated after VEGF, bFGF and VEGF+bFGF treatment and are therefore considered participants in pro-angiogenic signaling.

FGFs including aFGF and bFGF are implicated in maintenance of tumors often by mediating angiogenesis [35]. aFGF is a growth factor for capillary blood vesselsand involved in the stimulation of DNA synthesis and the proliferation of a wide variety of cell types [36]. It plays an important role in morphogenesis, angiogenesis and wound healing $[2,15,37]$.

\section{A method for expressing large amounts of recombinant proteins in higher plants}

In 1997 an intact leaf vacuum infiltration system for transient expression of recombinant proteins by Agrobacterium was applied to Phaseolus acutifolius, Phaseolus vulgaris, poplar and tobacco [16]. Vacuum was exerted on detached leaves and the plant materials were difficult to preserve fresh after inoculation. Green et al. used this method to express three therapeutic proteins: hGH, HAWY1, and LicKM-PAD4 in Pisum sativum 


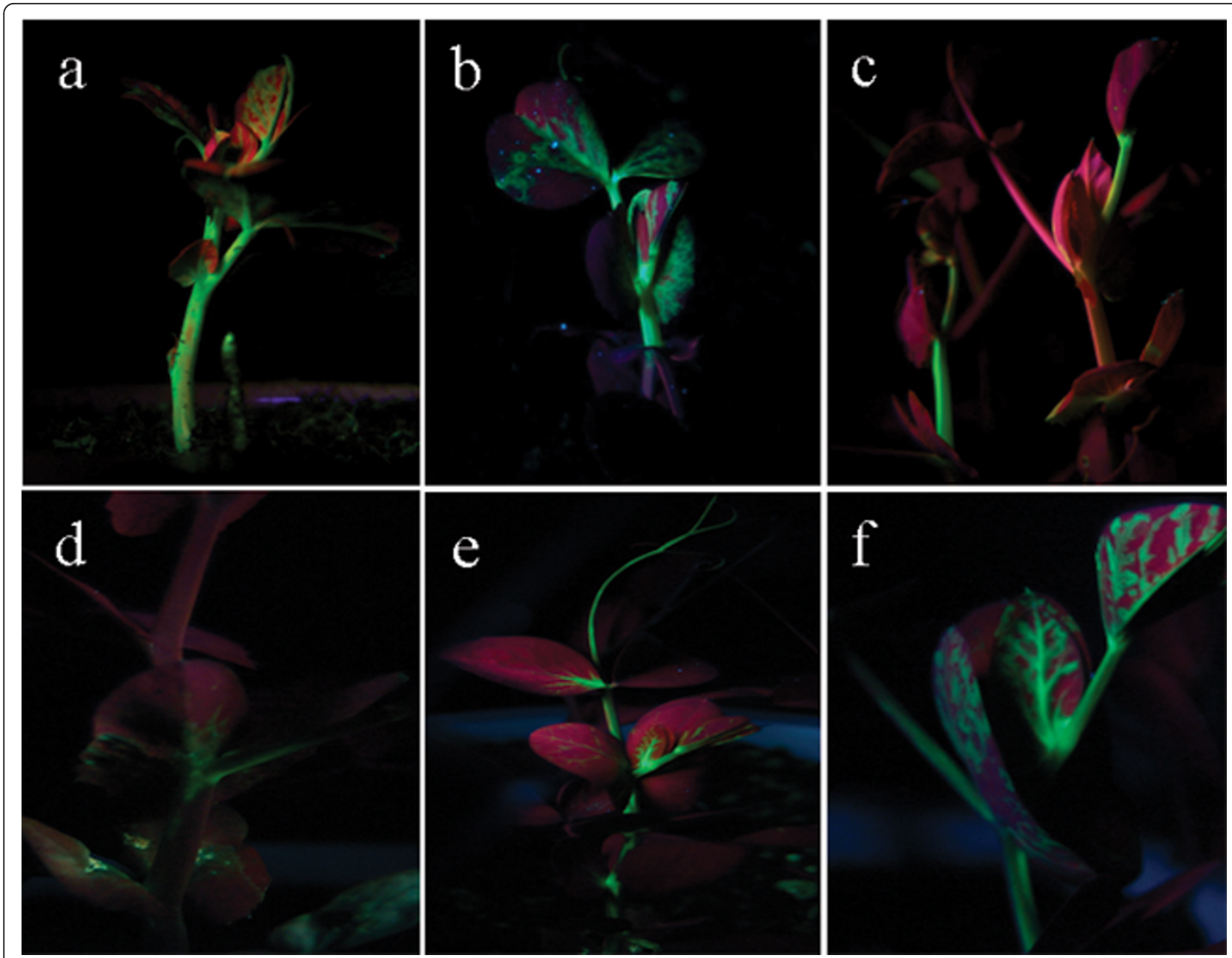

Figure 3 Examples of GFP expression in pea plants after agroinfection with the two agrobacterium strains GV3101 one carrying pCAPE2-GFP and the other pCAPE1. $a, b$ and c: agroinfection plants produced by vacuum infiltration of germinated seeds, $d$, e and f: agroinfection plants obtained by leaf injection. (a) 9 dpi, (b) 12 dpi, (c) 26 dpi, (d) 9 dpi, (e) 11 dpi, (f) 12 dpi.

(green pea) varieties. In contrast to our method the plants were grown for 7-14 days before vacuum infiltration [22]. In our study vacuum infiltration was applied to germinated pea seeds with $2-3 \mathrm{~cm}$ roots and factors influencing expression efficiency such as vacuum pressure, vacuum duration and bacterial density have been optimized. The optimal conditions for transient expression were a vacuum pressure at $0.08 \mathrm{MPa}$ for $1 \mathrm{~min}$ with a bacterial $\mathrm{OD}_{600}$ greater than 0.9 . These parameters were decisive factors causing $80 \%$ of the treated plants to produce the desired recombinant GFP.

\section{Conclusions}

When the modified pea early browning virus genomes with the targeted marker GFP were multiplied and spread in pea plants after inoculation, the GFP was concomitantly expressed at a high level. In the vacuum infiltrated seedlings GFP was first expressed in the stem and thereafter in leaves and reached its highest value in both leaves and stems at 12-15 dpi. The vacuum infiltration method, gives similar high yields to leaf injection but is more efficient. Time consuming leaf injection was avoided and the production cycle of plants was shortened from 30 days to 15 days. Mitogenic activity analysis demonstrated that the purified aFGF from pea plants stimulated the growth of NIH 3T3 cells. It is concluded that the reported procedure can provide large-amounts of functional recombinant proteins in pea and possibly other plants of interest. It can also be employed for virus induced gene silencing to study gene functions in a more effective way.

\section{Methods}

\section{Plasmid construction}

The unsuitable NcoI site of the pCAPE2 vector was modified to synthesise a $B g l \mathrm{II}$ for insertion of the $a F G F$ 


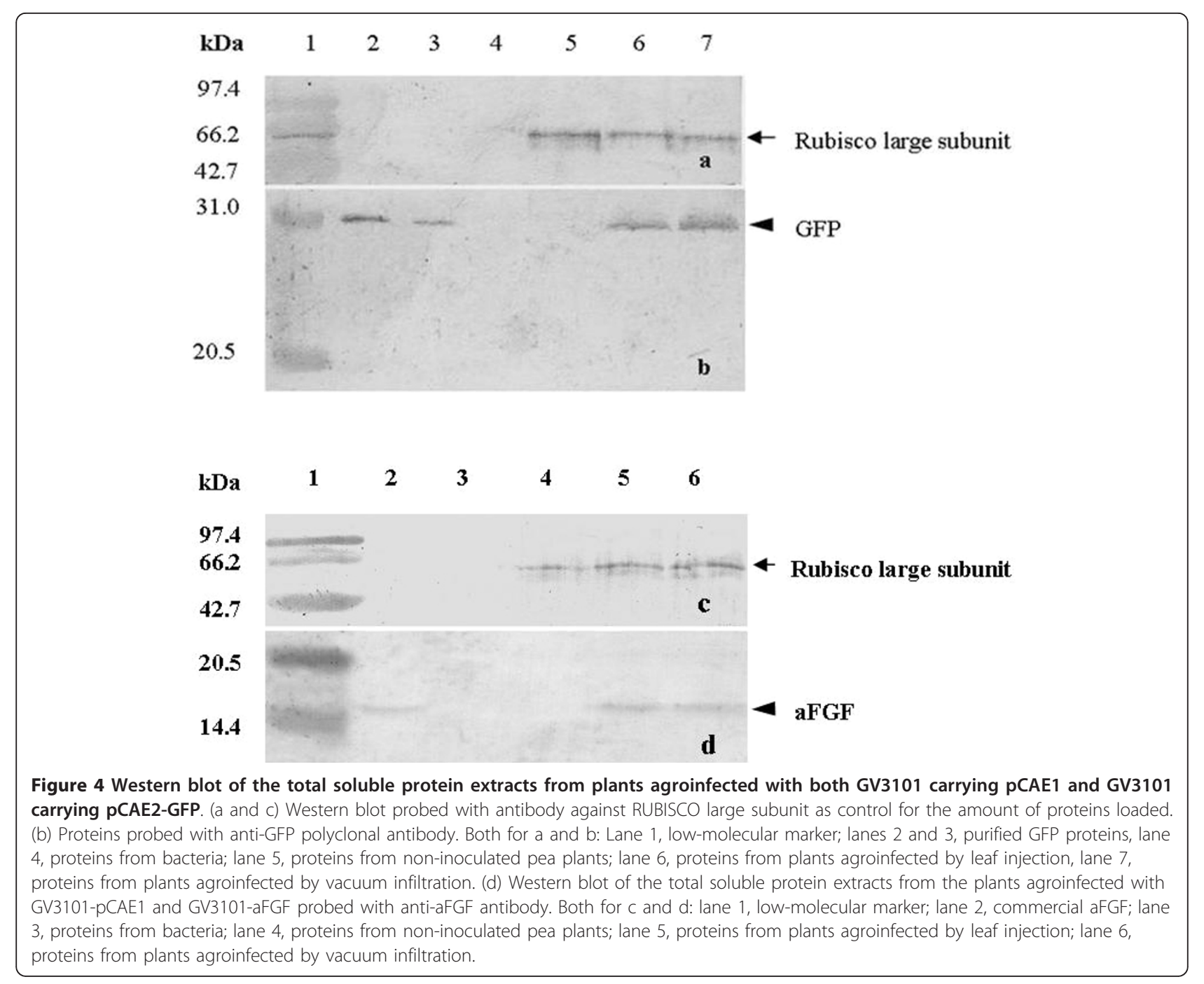

\section{Mitogenic effects of plant aFGF on NIH 3 T3 cells}

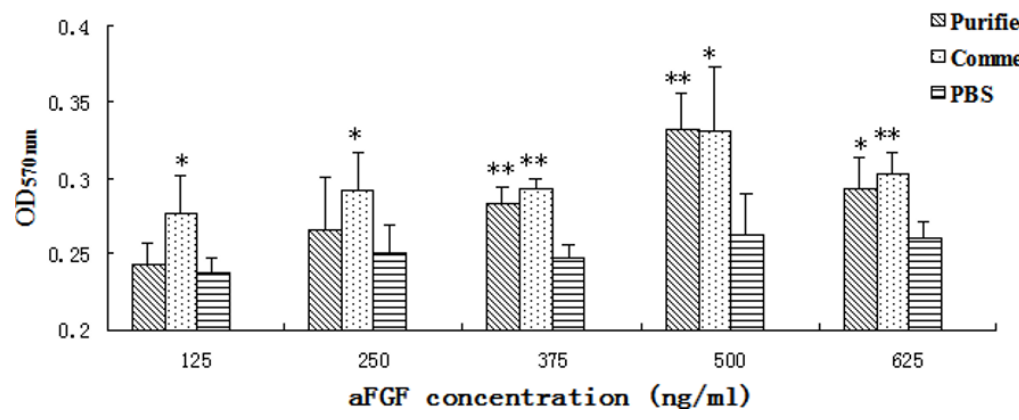

Figure 5 Induction of mitogenic activity of NIH 3 T3 cells by pea plant-derived aFGF. Commercial or plant expressed aFGF in PBS (20 mmol/l sodium phosphate $(\mathrm{pH} 7.4)$ containing $0.6 \mathrm{~mol} / \mathrm{I} \mathrm{NaCl}$ ) was used as postive control and PBS as negative control. ${ }^{*} p<0.05$, ,* $p<0.01$ as compared with PBS control. 
(A01474) sequence from the pET28-haFGF construct (provided by Dr X. Li, Jilin Agricultural University, Changchun, China). Forward (F) and reverse (R) primers to amplify the $a F G F$ fragment with unique BglII and EcoRI sites were designed: 5'-GGAAGATCTACATG GCTGAAGGGGAAATCAC-3'(F) and 5'-CGGAATTC TTAATCAGAAGAGACTGGCAGG-3'(R). The BglIIEcoRI PCR fragment was subcloned into pCAPE2 by replacement of the GFP sequence (Figure 1a, 1b show the PEBV vectors), and the new vector was named pCAPE2-aFGF.

\section{Plant materials and growth condition}

American dwarf pea P. sativum was obtained from the local market. The seeds were soaked in water for 6-8 hours and germinated on moist filter paper in the dark for $36-48$ hours at $25^{\circ} \mathrm{C}$. A part of germinated seeds were then vacuum infiltrated (see details below), and the others were planted in pots for leaf injection. Plants were grown in a plant growth chamber at $25^{\circ} \mathrm{C}$ under a $16 \mathrm{~h}$ cool fluorescent light $/ 8 \mathrm{~h}$ dark cycle.

\section{Plasmid introduction to Agrobacterium}

The binary vectors pCAPE2-aFGF, pCAPE2-GFP and pCAPE1 were introduced into Agrobacterium tumefaciens strain GV3101 by the freeze-thaw method [38]. Individual clones were grown in $200 \mathrm{ml} \mathrm{LB}$ with $50 \mu \mathrm{g}$. $\mathrm{ml}^{-1}$ rifampicin, $50 \mu \mathrm{g} \cdot \mathrm{ml}^{-1}$ kanamycin and $25 \mu \mathrm{g} \cdot \mathrm{ml}^{-1}$ tetracycline at $28^{\circ} \mathrm{C}$ for $12-16 \mathrm{~h}$ with shaking. At $\mathrm{OD}_{600}$ $=1.0-1.5$ the bacteria were harvested by centrifugation $(3500 \mathrm{~g})$ at room temperature. Cells were resuspended in infiltration medium $\left(10 \mathrm{mM} \mathrm{NaCl}, 1.75 \mathrm{mM} \mathrm{CaCl}_{2}\right.$, $100 \mu \mathrm{M}$ acetosyringone and $250 \mu \mathrm{g} \cdot \mathrm{L}^{-1}$ Tween $20, \mathrm{pH}$ 5.6) and incubated at room temperature for $90 \mathrm{~min}$ without shaking.

\section{Agrobacterium vacuum infiltration procedure}

Agrobacterium culture harboring pCAPE1 was mixed with culture harboring PCAPE2-GFP 1:1 v/v and infiltration medium. Alternatively Agrobacterium culture with pCAPE1 was combined with culture containing pCAPE2-aFGF 1:1 v/v with infiltration medium, prior to infiltration. Vacuum pressure, vacuum period, root wounding and bacterium suspension density were selected to optimize the induction of transient expressing plants by using the vacuum desiccator SHZ-D III (Yuhua Inc., Henan, China). Triplicate experiments with 20 seeds in each were carried out. Germinated seeds with roots of 2-3 cm were submerged in Agrobacterium suspensions (Figure 1). When the wounding treatment was used, the roots was pricked with a needle 1 to 2 times, whereafter the continuous vacuum was applied. The germinated seeds were planted in pots and 8 to 10 days post inoculation, GFP fluorescence was observed in seedlings using a $100 \mathrm{~W}$, long-wave UV lamp (Black Ray model B-100 AP; Ultra-Violet Products, Upland, CA, U. S.A.). Plants were photographed with a digital camera (Sony DSC-F828) mounted with yellow filters. In all the optimization treatments the percent of plants expressing GFP (GFP expression frequency) was used to estimate the treatment efficiency during 20 days post expression period. Acidic fibroblast growth factor (aFGF) was expressed in pea plants using the optimized seed vacuum infiltration system.

\section{Comparison of the expression level in vacuum infiltrated} germinated seeds versus leaf injection methods

Leaf injection was performed on 2-3 week old pea plants using a 1-ml syringe without needle $\left(\mathrm{OD}_{600}=1.2\right)$, The pea plants treated were then placed in the dark in a humid atmosphere for $24 \mathrm{~h}$ to recover from the treatment, whereas vacuum infiltration was conducted on the germinated seeds with $2-3 \mathrm{~cm}$ roots. Plants were monitored at 8-10 dpi and photographed. A total of 20 plants were harvested in each treatment and the total soluble proteins were extracted from pea plant leaves and stems. Western blot was used for determining the expression level and Bandscan software (Glyko Inc., USA) was used for estimating the amount of GFP.

\section{Western blot analysis of GFP and aFGF}

The plant material (8-10 dpi) were frozen in liquid nitrogen and pulverized. The powder was stirred in extraction buffer of $20 \mathrm{mM}$ sodium phosphate $(\mathrm{pH}$ 7.4) containing $0.6 \mathrm{M} \mathrm{NaCl}$, then centrifuged at $20817 \mathrm{~g}$ for $20 \mathrm{~min}$ at $4^{\circ} \mathrm{C}$. The supernatants were analyzed by $15 \%$ SDS-PAGE and then transferred to nitrocellulose membranes for immunoblotting. The murine polyclonal antibodies against GFP, Rubisco large subunit and aFGF were made in our laboratory. Antibodies bound to GFP protein, Rubisco large subunit protein and aFGF protein were visualized by chemiluminescent detection (SuperSignal WestPico Trial kit from Pierce). The proteins were extracted from GV3101-inoculated and control pea plants. The Western blot image was used to analyze protein expression quantity using Bandscan software.

\section{Purification and mitogenic activity analysis of pea plant- derived aFGF}

The pea plant-derived aFGF was purified by heparinaffinity chromatography. A heparin-Sepharose Column was washed with equilibration buffer $(0.6 \mathrm{M} \mathrm{NaCl}$ containing $20 \mathrm{mM}$ sodium phosphate $(\mathrm{pH} 7.4))$ and the total soluble protein of the Agroinfected plants applied. Bound proteins were eluted with elution buffer (1.2 M $\mathrm{NaCl}$ containing $20 \mathrm{mM}$ sodium phosphate (pH7.4)). The purified protein was then bioassayed for mitogenic activity. Commercial aFGF was used as the positive 
control and equilibration buffer was used as the negative control. NIH 3T3 cells (purchased from Shanghai Institute of Cell Biology, Chinese Academy of Sciences, Shanghai) were grown in IMDM (Gibco BRL, USA) medium supplemented with $10 \%(\mathrm{v} / \mathrm{v})$ fetal bovine serum (Gibco BRL, USA). When the culture reached the mid-exponential phase, cells were transferred to a 96well plate (5000 cells/well) and incubated in IMDM medium for $24 \mathrm{~h}$ and $12.5,25,37.5,50$, and $62.5 \mathrm{ng}$ aFGF were added to $100 \mu \mathrm{l}$ cell culture respectively. Four repeats of each treatment were made. After $24 \mathrm{~h}$ incubation $20 \mu \mathrm{l}$ of MTT [3-(4, 5-dimethylthiazol-2-yl)2, 5-diphenyl- $2 \mathrm{H}$-tetrazolium bromide; $5 \mathrm{mg} \cdot \mathrm{ml}^{-1}$ ] were added to each well and incubation continued for $6 \mathrm{~h}$ to determine the number of viable cells. After discarding the medium, $150 \mu \mathrm{l}$ of DMSO was added to each well, and the plate was kept at $37^{\circ} \mathrm{C}$ for $30 \mathrm{~min}$. The viable cell number was measured by the absorption of $570 \mathrm{~nm}$ as described in [15].

\section{Acknowledgements}

We thank Dr. Gabriela Constantin, Danish Institute of Agricultural Sciences for the gift of plasmids of pCAE1 and pCAE2-GFP. This work was supported by the Programme of Introducing Talents of Discipline to Universities Project B07017, the Program for Changjiang Scholars and Innovative Research Team (PCSIRT) in University (\#IRT0519), the Chinese National Plant Transformation Center (Grant No. JY03-B-17-01) and Jilin Provincial Project 20050704-2.

\section{Author details}

${ }^{1}$ Institute of Genetics and Cytology, Northeast Normal University, Changchun 130024, China. ${ }^{2}$ Department of Biology, Changchun Normal University, Changchun 130032, China. ${ }^{3}$ Yunnan-Guizhou Plateau Institute of Biodiversity, Qujing Normal University, Qujing 655000, China. ${ }^{4}$ College of Life Sciences, Jilin Agricultural University, Changchun 130118, China.

\section{Authors' contributions}

YF designed the study, performed the statistical analysis and drafted the manuscript. WL carried out the immunoassays. JW and JL purified aFGF protein and analyzed mitogenic activity. MY and DX constructed the plasmid, and dealt with the plant materials. XZ and XW conceived of the study, and participated in its design and coordination and helped to draft the manuscript.

Received: 15 September 2010 Accepted: 6 May 2011 Published: 6 May 2011

\section{References}

1. Pellegrini L, Burke DF, von Delft F, Mulloy B: Crystal structure of fibroblast growth factor receptor ectodomain bound to ligand and heparin. Nature 2000, 107:1029-1034

2. Burgess $\mathrm{WH}$, Maciag $\mathrm{T}$ : The heparin-binding (fibroblast) growth factor family of proteins. Annu Rev Biochem 1989, 58:575-606.

3. Folkman J: Angiogenesis. Ann Rev Med 2006, 57:1-18.

4. Ingber DE, Folkman J: Mechanochemical switching between growth and differentiation during fibroblast growth factor-stimulated angiogenesis in vitro, Role of extracellular matrix. J Cell Biol 1989, 109:317-330.

5. Kumagai M, Donson J, Della-Cioppa G, Grill LK: Rapid, high-level expression of glycosylated rice a-amylase in transfected plants by an RNA viral vector. Gene 2006, 245:169-174.

6. Jia HG, Pang $Y$, Chen $X$, Fang $R$ : Removal of the selectable marker gene from transgenic tobacco plants by expression of Cre recombinase from a Tobacco mosaic virus vector through agroinfection. Transgenic Res $2006,15: 375-384$.
7. Marillonnet S, Thoeringer C, Kandzia R, Klimyuk V, Gleba Y: Systemic Agrobacterium tumefaciens-mediated transfection of viral replicons for efficient transient expression in plants. Nat Biotechnol 2005, 23:718-723.

8. Varsani A, Williamson A, Stewart D, Rybicki E: Transient expression of Human papillomavirus type 16 L1 protein in Nicotiana benthamiana using an infectious tobamovirus vector. Virus Res 2006, 120:91-96.

9. Murphy A, Gilliland A, York C, Hyman B, Carr J: High-level expression of alternative oxidase protein sequences enhances the spread of viral vectors in resistant and susceptible plants. J Gen Virol 2004, 85:3777-3786.

10. Jia HG, Pang $Y$, Fang R: Agroinoculation as a simple way to deliver a tobacco mosaic virus-based expression vector. Acta Botanica Sinica 2003, 45:770-773.

11. Ramírez N, Rodríguez M, Ayala M, Cremata J, Pérez M, Martinez A, Linares M, Hevia Y, Páez R, Valdés R, Gavilondo JV, Selman-Housein G: Expression and characterization of an anti-(hepatitis $B$ surface antigen) glycosylated mouse antibody in transgenic tobacco (Nicotiana tabacum) plants and its use in the immunopurification of its target antigen. Biotechnol Appl Biochem 2003, 38:223-230.

12. Ramírez N, Ayala M, Lorenzo D, Palenzuela D, Herrera L, Doreste V, Pérez M, Gavilondo J, Oramas P: Expression of a single-chain Fv antibody fragment specific for the Hepatitis B surface antigen in transgenic tobacco plants. Transgenic Res 2002, 11:61-64.

13. Yusibov V, Modelska A, Steplewski K, Agadjanyan M, Weiner D, Hooper DC, Koprowski $\mathrm{H}$ : Antigens produced in plants by infection with chimeric plant viruses immunize against rabies virus and HIV-1. Proc. Natl Acad Sci USA 1997, 94:5784-5788.

14. Negrouk V, Eisner G, Lee HI, Han K, Taylor D, Wong H: Highly efficient transient expression of functional recombinant antibodies in lettuce. Plant Sci 2005, 169:433-438.

15. Liu JY, Ma PD, Sun Y, Yang MY, Yang LP, Li Y, Wu YF, Zhu XJ, Wang XZ: Expression of human acidic fibroblast growth factor in Nicotiana benthamiana with a potato-virus-X-based binary vector. Biotechnol Appl Biochem 2007, 48:143-147.

16. Kapila J, Rycke R, Montagu M, Angenon G: An Agrobacterium-mediated transient gene expression system for intact leaves. Plant Sci 1997, 122:101-108.

17. Orzaez D, Mirabel S, Wieland WH, Granell A: Agroinjection of tomato fruits. A tool for rapid functional analysis of transgenes directly in fruit. Plant Physiol 2006, 140:3-11.

18. Rao MVR, Rao GJN: Agrobacterium-mediated transformation of indica rice under Acetosyringone-free conditions. Plant Biotechnology 2007 24:507-511.

19. Wang $H$, Hao J, Chen X, Hao Z, Wang X, Lou Y, Peng Y, Guo Z: Overexpression of rice WRKY89 enhances ultraviolet $B$ tolerance and disease resistance in rice plants. Plant Mol Biol 2007, 65:799-815.

20. Arazi T, Lee Huang P, Huang PL, Zhang L, Moshe SY, Gal-On A, LeeHuang S: Production of Antiviral and Antitumor Proteins MAP30 and GAP31 in Cucurbits Using the Plant Virus Vector ZYMV-AGIl. Biochem Biophys Res Commun 2002, 292:441-448.

21. Vlahova M, Stefanova G, Petkov P, Barbulova A, Petkova D, Kalushkov P, Atanassov A, AgroBiolnstitute, Sofia, Bulgaria : Genetic modification of alfalfa (Medicago sativa L.) For quality improvement and production of novel compounds. Biotechnol \& Biotechnol 2005, 19:56-62.

22. Green BJ, Fujiki M, Mett V, Kaczmarczyk J, Shamloul M, Musiychuk K Underkoffler $S$, Yusibov $V$, Mettet $V$ : Transient protein expression in three Pisum sativum (green pea) varieties. Biotechnol J 2009, 4:230-237.

23. Constantin GD, Krath BN, MacFarlane SA, Nicolaisen M, Johansen IE, Lund OS: Virus-induced gene silencing as tool for functional genomics in a legume species. Plant J 2004, 40:622-631.

24. MacFarlane S: Molecular biology of the tobraviruses. J Gen Virol 1999, 80:2799-2807

25. MacFarlane S, Popovich A: Efficient Expression of Foreign Proteins in Roots from Tobravirus Vectors. Virology 2000, 267:29-35.

26. Chapman S, Kavanagh T, Baulcombe D: Potato virus $X$ as a vector for gene expression in plants. Plant J 1992, 2:549-557.

27. Ratcliff F, Martin-Hernandez AM, Baulcombe DC: Tobacco rattle virus as a vector for analysis of gene function by silencing. Plant J 2001, 25:237-245

28. MacFarlane S: Tobraviruses-plant pathogens and tools for biotechnology. Molecular Plant Pathology 2010, 11:577-583.

29. Wang D, MacFarlane S, Maule A: Viral Determinants of Pea Early Browning Virus Seed Transmission in Pea. Virology 1997, 234:112-119. 
30. Vaquero C, Sack M, Chandler J, Drossard J, Schuster F, Monecke M, Schillberg S, Fischer R: Transient expression of a tumor-specific singlechain fragment and a chimeric antibody in tobacco leaves. Proc Natl Acad Sci USA 1999, 96:11128-11133.

31. Li J, Chen M, Liu XW, Zhang HC, Shen FF, Wang GP: Transient expression of an active human interferon-beta in lettuce. Scientia Horticulturae 2007, 112:258-265.

32. Mahmoudian M, Yücel M, Öktem H: Transformation of Lentil (Lens culinaris M.) Cotyledonary Nodes by Vacuum Infiltration of Agrobacterium tumefacien. Plant Molecular Biology Reporter 2002, 20:251-257.

33. Abdollahi A, Schwager C, Kleff J, Esposito I, Domhan S, Peschke P, Hauser K, Hahnfeldt P, Hlatky L: Transcriptional network governing the angiogenic swich in human pancreatic cancer. Proc Natl Acad Sci 2007, 104:12890-12895.

34. Jensen RL: Growth factor-mediated angiogenesis in the malignant progression of glial tumors: a review. Surg Neurol 1998, 49:189-195.

35. Grose R, Dickson C: Fibroblast growth factor signaling in tumorigenesis. Cytokine Growth Factor Rev 2005, 16:179-186.

36. Slavin J: Fibroblast growth-factors-at the heart of angiogenesis. Cell Biology International 1995, 19:431-444.

37. Basilico C, Moscatelli D: The FGF family of growth factors and oncogenesis. Adv Cancer Res 1992, 59:115-65.

38. Holsters M, de Waele D, Depicker A, Messens E, van Montagu M, Schell J: Transfection and transformation of Agrobacterium tumefaciens. Mol Gen Genet 1978, 163:181-187.

doi:10.1186/1472-6750-11-45

Cite this article as: Fan et al.: Efficient production of human acidic fibroblast growth factor in pea (Pisum sativum L.) plants by agroinfection of germinated seeds. BMC Biotechnology 2011 11:45.

\section{Submit your next manuscript to BioMed Central and take full advantage of:}

- Convenient online submission

- Thorough peer review

- No space constraints or color figure charges

- Immediate publication on acceptance

- Inclusion in PubMed, CAS, Scopus and Google Scholar

- Research which is freely available for redistribution

Submit your manuscript at www.biomedcentral.com/submit
C Biomed Central 